\title{
HIDROLOŠKA ANALIZA IZVORIŠNOG DIJELA RIJEKE GACKE
}

\author{
HYDROLOGICAL ANALYSIS OF THE SOURCE \\ REGION OF THE GACKA RIVER
}

\author{
Marijana Fišić*, Josip Rubinić*, Maja Radišić*
}

\begin{abstract}
Sažetak
U ovom radu provedena je hidrološka analiza voda izvorišnog dijela rijeke Gacke. Provedene su standardne statističke obrade nizova podataka o karakterističnim mjesečnim i godišnjim protocima te analize krivulja recesije. Radi kompletiranja nizova podataka korištenih u analizi, provedeno je i produljivanje nizova podataka pomoću metoda strojnog učenja, pri čemu je provedena usporedba i diskusija rezultata modeliranja dobivenih po nekoliko upotrijebljenih modela neuronskih mreža i regresijskih stabala odlučivanja. Na temelju provedenih testiranja na nizovima podataka, koji nisu bili uključeni u generiranje modela, utvrđeno je da se korištenim modelima mogu dobro nadomjestiti nedostajući nizovi podataka.
\end{abstract}

Ključne riječi: rijeka Gacka, izvori u kršu, krivulja recesije, metode strojnog učenja

\begin{abstract}
The paper contains a hydrological analysis of the source region of the Gacka River. Standard statistical analyses of data series about the characteristic monthly and annual discharges and recession curve analyses were made. In order to complete the data series used in the analyses, data series were extended using machine learning methods, comparing and discussing the modelling results obtained from several neural network and regression decision tree models used. Based on the conducted testing of the data series that weren't included in the model generation, it was identified that the models used can properly replace the missing data series.
\end{abstract}

Keywords: Gacka River, karst springs, recession curve, machine learning methods

${ }^{*}$ Sveučilište u Rijeci, Građevinski fakultet, Radmile Matejčić 3, 51000 Rijeka

E-mail: \{jrubinic,maja.radisic\}@uniri.hr; marijanafisic@gmail.com 


\section{Uvod}

Rijeka Gacka kao jedna od većih ponornica u svijetu čini jedno od najvećih bogatstava, ali i fenomena Dinarskog krša. Njeno bogatstvo se ogleda u njenim površinskim i podzemnim vodnim resursima. Svoj tok započinje nizom povremenih i stalnih izvora, a dužinom svog toka u iznosu od $61 \mathrm{~km}$ [1] dodatno se obogaćuje brojnim pritokama lijeve i desne obale. $\mathrm{S}$ vrlo ustaljenim tokom, s relativno malo oscilacija razina i protoka, protječe istoimenim krškim poljem (Gacko polje) koje je smješteno u središnjem dijelu Ličko-senjske županije.

Hidrološka analiza je provedena u cilju osiguranja detaljnijih spoznaja o vodnom režimu njenih izvora i njihovih međuodnosa. Provedene su godišnje i mjesečne analize raspodjele protoka za recentno razdoblje od 1997. - 2016. godine na postajama izvor Gacka, Sinac -Tonković vrelo, Ličko Lešće-izvor Pećina i Čovići-vodotok Gacka. Provedene su i analize krivulja recesije uz koju je dodatno izvršena procjena napajanja podzemne vode između dvije krivulje recesije pomoću programskog alata Visual Basic macro [2]. U sklopu hidrološke analize također je provedeno modeliranje podataka na osnovu kojeg se izvelo produžavanje niza podataka o protocima. Pri tom su korišteni modeli strojnog učenja - neuronske mreže i regresijska stabla odlučivanja. Uz pomoć dvaju varijanti formiranja nizova ulaznih podataka izrađena su dva modela te je provedena usporedba njihovih rezultata. Oba modela temelje se na 1 nezavisnoj varijabli, s tim da je u prvom modelu uzeta 1 varijabla (protok) s 4 postaje, dok je u drugom modelu uzeta također jedna varijabla ali za 4 različita trajanja (dnevni protoci, srednja vrijednost protoka za 15, 30 i 60 dana) s 3 postaje.

\section{Opće karakteristike analiziranog područja}

Dolina rijeke Gacke smještena je u području visokog krša Ličko-senjske županije, pripadajući time i području Ličkog sredogorja [3]. Rijeka Gacka svojim tokom protječe kroz Gacko polje prihranjivajući se brojnim stalnim ili povremenim krškim izvorima, od kojih su najznačajniji izvor Gacke, Tonković vrelo i Majerovo velo te izvor Pećina. Gacko polje je najniže krško polje tog područja s nadmorskom visinom od 450 do $470 \mathrm{~m}$ n.m. te pripadajućom površinom od $8,0 \mathrm{~km}^{2}$ [4], kojim dominira umjereno kontinentalna klima sa svježim ljetima. Prosječna godišnja temperatura prema podacima Državnog hidrometeorološkog zavoda (DHMZ-a) u periodu od 1971. do 2000. kreće se u intervalu od 6 do $10{ }^{\circ} \mathrm{C}$ [5], dok prosječna godišnja oborina za period od 1961. do 1990. iznosi oko $1150 \mathrm{~mm}$ [6]. Na Slici 1 dan je prikaz korištenih hidroloških, klimatoloških i kišomjernih postaja pri izradi ove analize. 


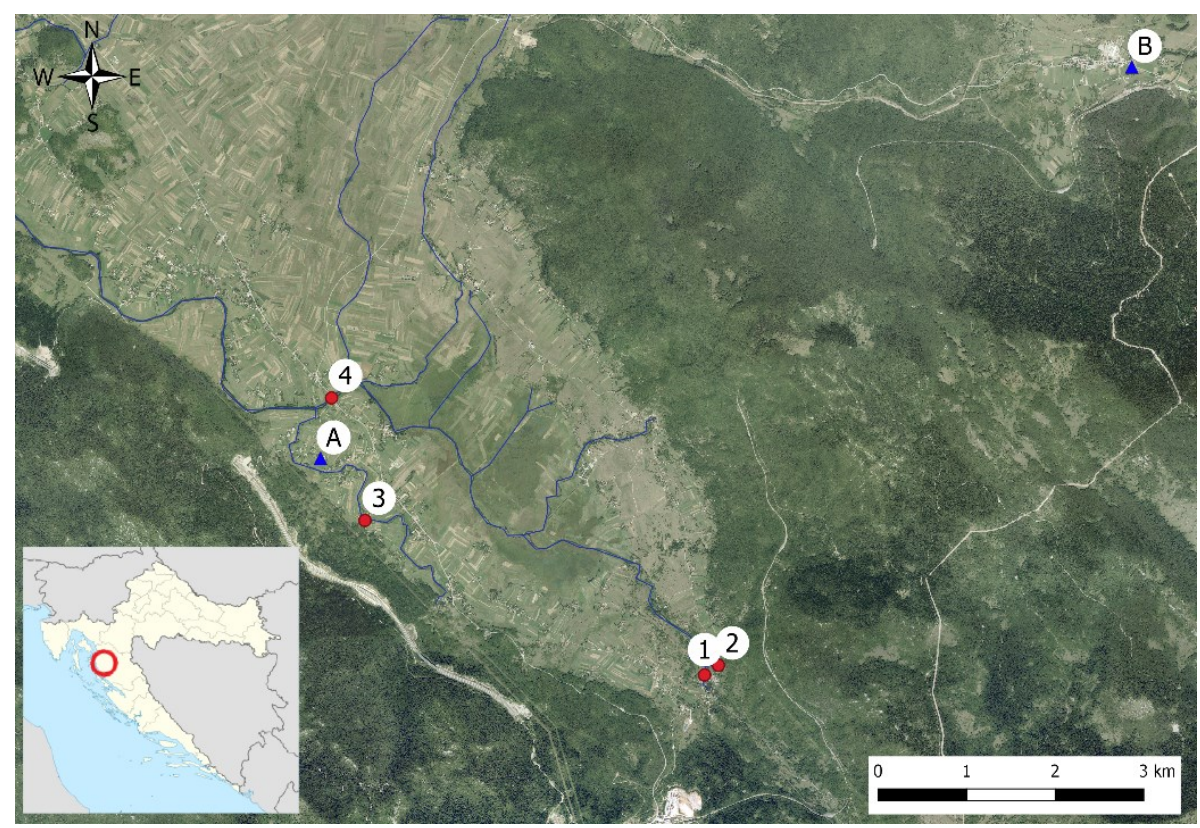

Slika 1. Prikaz položaja izvorišnog dijela rijeke Gacke s ucrtanim hidrološkim (1Izvor Gacke, 2-Sinac-Tonkovića vrelo, 3-Ličko Lešće-izvor Pećina, 4-Čovići-Gacka), klimatološkim (A-Lićko Lešće) i kišomjernim postajama (B-Vrhovine)

Karakterističnost analiziranog područja ogleda se u složenosti geoloških, geomorfoloških, hidroloških i hidrogeoloških struktura. Na području Gackog polja dominiraju okršene karbonatne stijene donjokredne starosti, odnosno vapnenci i vapnenača breča te jelar naslage koje su vrlo heterogene klastične [7]. Također, karakterističan je visoki razvoj krških formi i tipične krške hidrogeologije s pojavama velikih krških polja, jama i špilja te pojava istjecanja voda putem brojnih stalnih ili povremenih krških izvora. Na području Gackog polja procesi okršavanja i dan danas se odvijaju u području rasjednih i pukotinskih sustava smjera pružanja SI-JZ i S-J, gdje se formiraju tokovi podzemnih voda, što ima značajan utjecaj na složenost hidroloških i hidrogeoloških struktura. Površina sliva rijeke Gacke prema Planu upravljanja vodnim područjem [1] procjenjuje se na $584 \mathrm{~km}^{2} \mathrm{~s}$ prosječnim protokom od $13,3 \mathrm{~m}^{3} / \mathrm{s}$ te pripada Jadranskom vodnom području (JVP) čija je ukupna površina $35303 \mathrm{~km}^{2}$ [1]. Sliv rijeke Gacke ima slabo razvijenu hidrografsku mrežu [8], ali i izrazito ustaljeni tok vode, što nikako nije jedna od karakteristika krških rijeka [6], ali upravo ta ustaljenost Gacku čini specifičnom krškom rijekom.

Jedna od karakteristika sliva je da ima veliku retencionu sposobnost podzemlja [9] te da glavninu dotoka dobiva podzemnim putem. Podzemna retencija, odnosno krški vodonosnik s vrlo razvijenim akumulacijskim sposobnostima snažno djeluje na izravnanje vode, što uvjetuje povoljnu 
vodnost rijeke i u malovodnom režimu [10]. U kišnom periodu on ima funkciju drena podzemne vode, dok se u sušnom ta funkcija ogleda $u$ prihranjivanju podzemlja [10].

\section{Podloge i metodologija provedbe hidrološke analize}

Hidrološka analiza u ovom radu provedena je na osnovu podataka DHMZ-a o protocima za razdoblje od 1997. do 2016. godine na postajama Izvor Gacka, Sinca-Tonković vrelo, Ličko Lešće-izvor Pećina i Čovići-Gacka, ujedno i najnizvodnijoj postaji koja se nalazi na vodotoku Gacke. Pri tome je važno spomenuti da su se za godišnje i mjesečne analize koristile hidrološke godine.

Na Slici 1 prikazana je karta analiziranog područja s ucrtanim prethodno navedenim hidrološkim postajama DHMZ-a te klimatološkim (Ličko Lešće) i kišomjernim postajam (Vrhovine) čiji su podaci o oborinama korišteni u razdoblju od 2008. do 2016. godine.

Metodologija izrade ovog rada sastojala se u nekoliko tipova analiza. Prije svega provedena je osnovna statistička obrada karakterističnih mjesečnih i godišnjih protoka, analiza krivulja recesije uz koju je provedena i procjena napajanja podzemlja te modeliranje podataka pomoću tzv. metoda strojnog učenja.

Pri analiziranju krivulja recesije korišteni su dnevni podaci o protocima na postaji Čovići-Gacka i izvor Gacka, a korišten je izraz prema Maillet-u [11]. Na osnovu izraza prema Maillet-u (1) dobiveni su koeficijenti recesije (2) koju upućuju na brzinu dreniranja njihova vodonosnika

$$
Q(t)=Q_{0}\left(t_{0}\right) * e^{-\alpha *\left(t-t_{0}\right)}
$$

gdje su: $\mathrm{Q}(\mathrm{t})$ - protok u trenutku $\mathrm{t}, \mathrm{Q}_{0}\left(\mathrm{t}_{0}\right)$ - protok u proizvoljnom trenutku $t_{0}$ koji prethodi trenutku $t$, e - baza prirodnog logaritma, $\alpha-$ koeficijent recesije (koeficijent pražnjenja vodonosnika), ( $\left.t-t_{0}\right)$ - vrijeme trajanja recesije. Vrijednost koeficijenta $\alpha$ ovisi o retencijskim karakteristikama podzemnog rezervoara, tj. o transmisivnosti i specifičnom uskladištenju, a proračunava se prema izrazu:

$$
\alpha=-\frac{1}{t} * \ln \left(\frac{Q_{t}}{Q_{0}}\right)
$$

Prema Krešiću [12], koeficijent recesije $\alpha>10^{-2}$ upućuje na brzo dreniranje krupnih krških kanala i pukotina, dok $\alpha<10^{-3}$ ukazuje na sporo dreniranje vode iz manjih pora i pukotina, tj. dominaciju stijenskog matriksa u toku vode kroz krško podzemlje. Što je koeficijent recesije veći, krivulja recesije je strmija i obrnuto. 
Također, uz analizu krivulje recesije na postaji Čovići izvršena je i procjena količine napajanja podzemne vode pomoću alata Visual Basic macro (VBM) [2], čiji proračun su izradili Posavec i suradnici [2].

Kako bi se dobila veličina napajanja podzemne vode koristi se eksponencijalna funkcija [2], dana u vidu jednadžbe (3):

$$
Q=\frac{Q_{0}}{10^{t / t_{1}}}
$$

gdje je $\mathrm{Q}_{0}$ jednako pražnjenu u vremenu $\mathrm{t}=0, \mathrm{t}_{1}$ je vrijeme 1 log ciklusa koji slijedi nakon vremena $t$ - koje je jednako vremenu tj. trenutku promatranja, za koje pražnjenje baznog toka odgovara recesiji:

$$
V o l=\int_{t_{0}}^{t} Q d t=-\left.\frac{Q_{0} t_{1} / 2,3}{10^{t / t_{1}}}\right|_{t_{0}} ^{t}
$$

Integracijom jednadžbe (3), na način kako je to prikazano u jednadžbi (4) može se dobiti ukupni volumen baznog toka (5) koji se naziva „ukupno potencijalno pražnjenje podzemne vode" $\mathrm{V}_{\mathrm{tp}}$ :

$$
V_{t p}=\frac{Q_{0} t_{1}}{2,3}
$$

Stvarno pražnjenje volumena baznog toka tijekom ukupne recesije može se izračunati integracijom jednadžbe (3) od vremena $t_{0}$ do kraja recesije, na način kako je to opisano u jednadžbi (4). Taj volumen naziva se „stvarno pražnjenje podzemne vode“ - $\mathrm{V}_{\mathrm{a}}$ i računa se prema izrazu:

$$
V_{a}=\frac{Q_{0} t_{1}}{2,3}-\frac{\frac{Q_{0} t_{1}}{2,3}}{10^{t / t_{1}}}
$$

Razlikom ukupnog potencijalnog pražnjenja $V_{\text {tp }}$ (5) i stvarnog pražnjenja podzemne vode $\mathrm{V}_{\mathrm{a}}$ (6) dobiva se "preostalo potencijalno pražnjenje podzemne vode" $-\mathrm{V}_{\mathrm{r}}$ :

$$
V_{r}=V_{t p}-V_{a}
$$

Primjenom jednadžbi (3), (4) i (5) Meyboom [13] je dao procjenu napajanja podzemne vode između recesija. Unutar alata VBM Meyboom-ova metoda je prilagođena, a sastoji se u prilagodbi eksponencijalnog regresijskog modela široko dostupnog u MS Excel-u do recesije baznog toka koji prethode i prate napajanje podzemne vode.

Meyboomova metoda temelji se na usporedbi recesijske krivulje za dane podatke protoka te u samoj osnovi procjenjuje količinu napajanja podzemne vode u rezorvaru.

Jedan od problema koji se često javlja pri analizama izvora ili rijeka su nekontinuirana mjerenja protoka/vodostaja ili pak nejednaki nizovi postojećih mjerenja na određenim postajama. Upravo u svrhu prevladavanja tog problema, uvelike je od pomoći dubinska analiza podataka koja je zasnovana na postupcima umjetne inteligencije, u prvom redu strojnog učenja, koje nam omogućava postizanje puno bolje funkcijske veze između raspoloživih podataka i traženih varijabli.

Pri dubinskoj analizi, u ovom radu korišten je programski paket WEKA [14] koji omogućuje cijeli proces automatskog pronalaženja uzoraka i 
pravilnosti među podacima, a uključuje pripremu ulaznih podataka, statističku evaulaciju procesa učenja i vizualizaciju ulaznih podataka odnosno rezultata strojnog učenja [14]. Radi se o računalnom alatu baziranom na objektno orijentiranom Java programskom jeziku koji omogućava više različitih pristupa strojnom učenju te sadrži najpoznatije algoritme strojnog učenja [14]. U danom slučaju su uz pomoć WEKE primijenjene dvije tehnike modeliranja: neuronske mreže i regresijska stabla odlučivanja. Osnovni princip u oba pristupa je strojno učenje na povijesno zabilježenim podacima. Pri modeliranju nekoga procesa nužno je dio raspoloživih podataka (obično oko $80 \%$ ) iskoristiti za treniranje, a preostali dio za validaciju modela.

Neuronske mreže su jedna od metoda umjetne inteligencije čiji je cilj pronaći skrivene veze među podacima. Jedinica za obradu podataka (varijabli) je umjetni neuron koji prima ponderirane ulazne vrijednosti od drugih varijabli, a prema nekoj formuli transformira primljenu vrijednost i zatim šalje izlaz drugim varijablama. U ovom radu, za modeliranje je korišten algoritam višeslojni perceptron (MultiLayer Perceptron-MP) koji se sastoji od više slojeva međusobno povezanih procesnih elemenata čvorova ili neurona (perceptrona). Višeslojni perceptron je vrlo prihvaćeni tip neuronskih mreža, prvenstveno zbog uvažavanja nelinearnosti te je pogodan za probleme predviđanja i klasifikacije.

Regresijska stabla odlučivanja jedna su od najpopularnijih i osnovnih metoda strojnog učenja. Klasifikacijski algoritam stabla odlučivanja čini forma stablaste strukture u kojoj su granama povezana dva tipa čvorova čvor odluke i krajnji čvor. U čvorovima odluke definirani su određeni uvjeti u obliku vrijednosti određenih atributa, na temelju čega se provodi testiranje. U krajnjim čvorovima završavaju određene grane stabla. [15]. Za potrebe ovog rada korišten je algoritam M5P.

Mana ove metode je da se greške javljaju pri većem broju korištenih klasa s relativno malim brojem nizom podataka za učenje, dok je prednost u generiranju čovjeku razumljivih modela te jasnoći prikaza važnosti atributa pri analizi problema kao što je npr. opadanje izdašnosti izvora. Za potrebe ovog rada izrađena su dva modela, a mjere koje su korištene pri ocijeni kvalitete modela su: koeficijent korelacije, srednja apsolutna pogreška (MAE, Jed. (8)) i korijen iz srednje apsolutne pogreške (RMSE, Jed. (9)).

$$
\begin{aligned}
& M A E=\frac{1}{n} \sum_{i=0}^{n}\left|y_{i}-\widehat{y}_{l}\right| \\
& R M S E=\sqrt{\frac{1}{n} \sum_{i=0}^{n}\left|y_{i}-\widehat{y}_{l}\right|}
\end{aligned}
$$

S obzirom da su dnevni podaci o protocima na postajama Izvor Gacke, Sinac-Tonkovića vrelo i Ličko Lešće-izvor Pećina kontinuirano mjereni u 
razdoblju od 6.1.1988. do 31.12.2016. godine, pomoću metoda strojnog učenja se pristupilo nadopunjavanju nedostajućih podataka na postaji Čović u razdoblju od 6.1.1988. do 31.12.1994.

\section{Rezultati analiza}

\subsection{Osnovne statističke obrade}

$\mathrm{Na}$ samom početku ove hidrološke analize provedena je osnovna statistička obrada godišnjih i unutargodišnjih podataka o protocima na već spomenute četiri postaje. Ustanovljene su srednje godišnje vrijednosti protoka na postaji Izvor Gacke od 2,92 $\mathrm{m}^{3} / \mathrm{s}$, Sinac-Tonković vrelo 3,06 $\mathrm{m}^{3} / \mathrm{s}$, Ličko Lešće-izvor Pećina $1,57 \mathrm{~m}^{3} / \mathrm{s}$ te na postaji Čovići $12,05 \mathrm{~m}^{3} / \mathrm{s}$. $\mathrm{Na}$ Slici 2 dan je prikaz srednjih godišnjih protoka i njihovi trendovi. Sa slike vidimo da je na sve četiri postaje zabilježen trend blagog porasta protoka, no on nije signifikantan prije svega zbog kratkog niza ulaznih podataka. Najveći rastući trend ima postaja Čovići u iznosu od $0,0478 \mathrm{~m}^{3} / \mathrm{s}$ godišnje, dok najmanji postaja Sinac s tek $0,0109 \mathrm{~m}^{3} / \mathrm{s}$ godišnje.

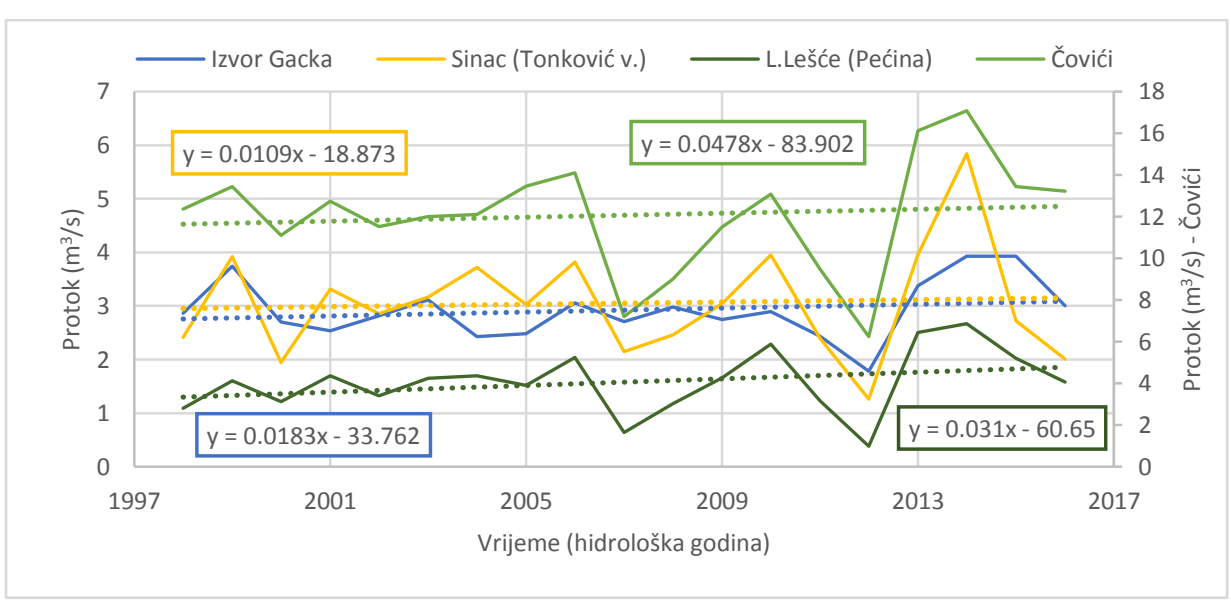

Slika 2. Hod srednjih godišnjih protoka za period od 1997.-2016.

Na Slici 3 dan je grafički prikaz usporedbe srednjih ukupnih mjesečnih oborina i srednjih mjesečnih protoka prikazanih $u$ modularnim vrijednostima. Vidno je da protoci imaju nekoliko mjeseci kašnjenje - prije svega u proljeće zbog otapanja snijega u slivu. Kašnjenje protoka u odnosu na oborine je najizražajnije na postaji Čovići i Ličko Lešće gdje vidimo da se maksimalne oborine na postaji Vrhovine i Ličko Lešće javljaju u mjesecu studenom, dok se maksimalni protoci javljaju tek u veljači. Nešto manja kašnjenja protoka u odnosu na oborine javljaju se na ostale dvije izvorišne postaje. Prosječna maksimalna mjesečna količina oborina vezana je uz 
studeni na postaji Vrhovine u iznosu od $164,8 \mathrm{~mm}$, a najniža na postaji Ličko Lešće u kolovozu u iznosu od 61,3 $\mathrm{mm}$. Usporedbom mjesečnih protoka postaja Izvor Gacka i Sinac u sušnom periodu vidno je da protoci na postaji Sinac značajnije padaju u prosjeku za razliku od izvora Gacke čiji su protoci u većini slučajeva ustaljeni, što ukazuje na različit karakter prihranjivanja ta dva prostorno vrlo bliska izvora.

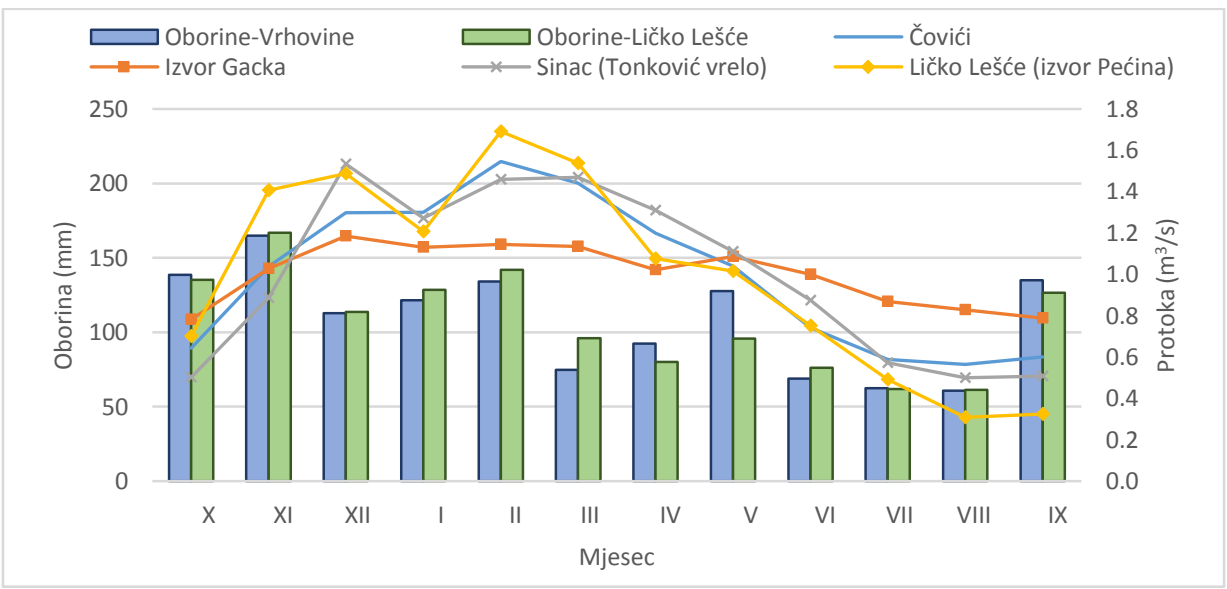

Slika 3. Prikaz odnosa srednjih mjesečnih oborina i protoka za period od 2008.2016 . godine

\subsection{Analiza krivulje recesije i procjena količine napajanja podzemlja}

Analiza krivulja recesija provedena je na osnovu podataka o dnevnim protocima na postaji Čovići (Slika 4) i Izvor Gacke (Slika 5). Grafički prikazi su dani u relativnim odnosima, odnosno s ishodištem $\mathrm{u}$ istoj vremenskoj točki. Na postaji Čovići sveukupno je analizirana 21 krivulja recesije, dok je na postaji Izvora Gacke analizirano tek 10 krivulja. Kako bi se usporedile krivulje recesija i time analiziralo na kojoj od postaja dolazi do bržeg pada otjecanja (na osnovu pretpostavljenog protoka i koeficijenta recesije) na danim postajama, prije svega je bilo potrebno odrediti njihove reprezentativne krivulje.

Izjednačenjem po dvaju odbranih krivulja (za početno i završno stanje recesije) dobivena je zajednička recesijska krivulja složenog sustava koja prikazuje realniji prikaz u prirodnom sustavu.

Na postaji Čovići, vizualnom analizom s grafičkog prikaza (Slika 4), odabrane su kao reprezentativne dvije krivulje $\mathrm{s}$ najdugotrajnijim razdobljima recesije - krivulje pod brojem 21 i 18 . Analogno tome, na postaji Izvora Gacke također su određene kao reprezentativne krivulje pod brojem 10 i 6 (Slika 5). U oba slučaja, odnosno krivulje pod rednim brojem 21 i 10 predstavljaju najdužu krivulju sa sporim pražnjenjem i dreniranjem, o čemu 
govori njen koeficijent recesije, dok krivulje 18 i 6 predstavljaju pražnjenje pri manjim protocima, ali s većim koeficijentom recesije.

Kombinacijom krivulja 21 i 18 (Slika 4) dobivena je mjerodavna jednadžba krivulje recesije (10) koja predstavlja složen režim pražnjenja podzemnih rezervi na vodotoku Gacke, odnosno postaji Čovići.

$Q_{t}=Q_{01} * e^{-0,0040 *\left(t-t_{01}\right)}+13,335 * e^{-0,0063 *\left(t-t_{02}\right)}$

Kombinacijom odabranih krivulja pod brojem 6 i 10 na postaji Izvor Gacka (Slika 5) dobivena je i za taj lokalitet mjerodavna jednadžba krivulje recesije (11) koja predstavlja također složen režim pražnjena podzemnih rezervi.

$Q_{t}=Q_{01} * e^{-0,026 *\left(t-t_{01}\right)}+4,632 * e^{-0,0024 *\left(t-t_{02}\right)}$

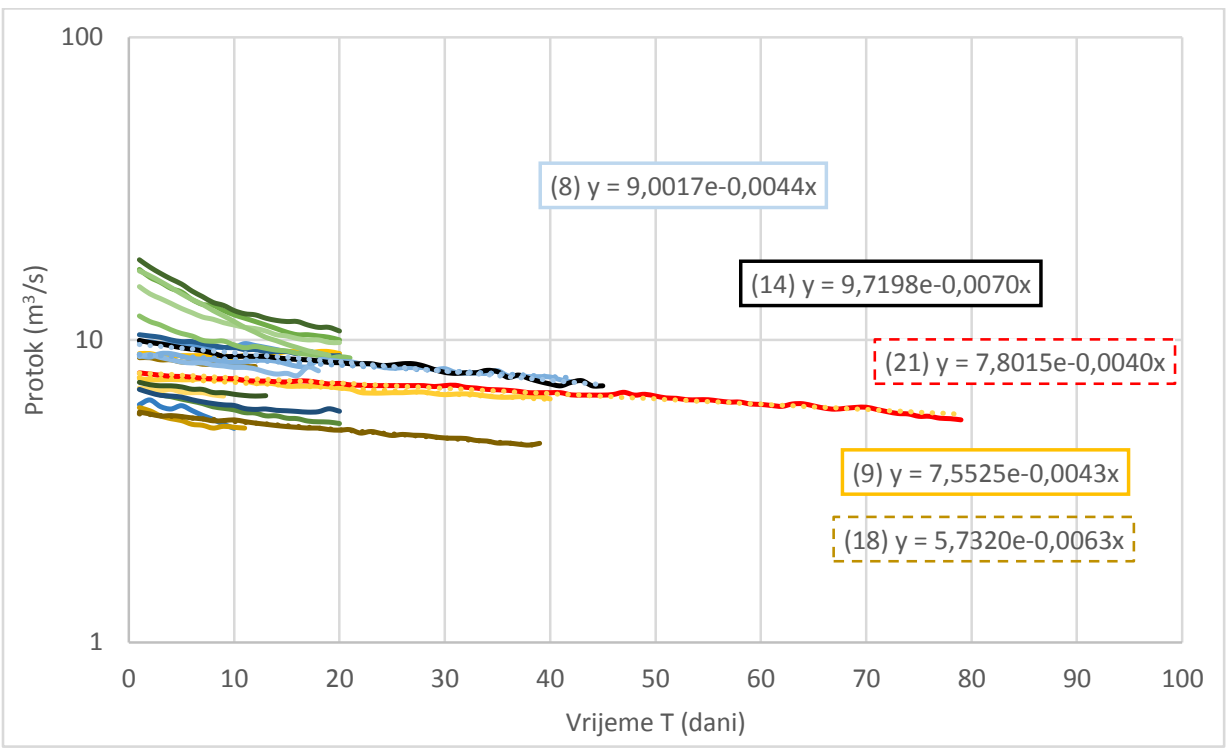

Slika 4. Krivulje recesije na postaji Čovići (1995.-2016.)

Na osnovu mjerodavnih jednadžbi recesije (10) i (11) provedena je usporedba ponašanja protoka na postaji Čovići i Izvor Gacka pri pražnjenju vodnih zaliha bez značajnijeg utjecaja oborina, a rezultati modela prikazani su u Tablici 1. Pri usporedbi mjerodavnih krivulja recesije korištena je kao pretpostavljena početna vrijednost protoka $-Q_{0}$, odnosno najmanja zabilježena u iznosu od $0,742 \mathrm{~m}^{3} / \mathrm{s}$. 


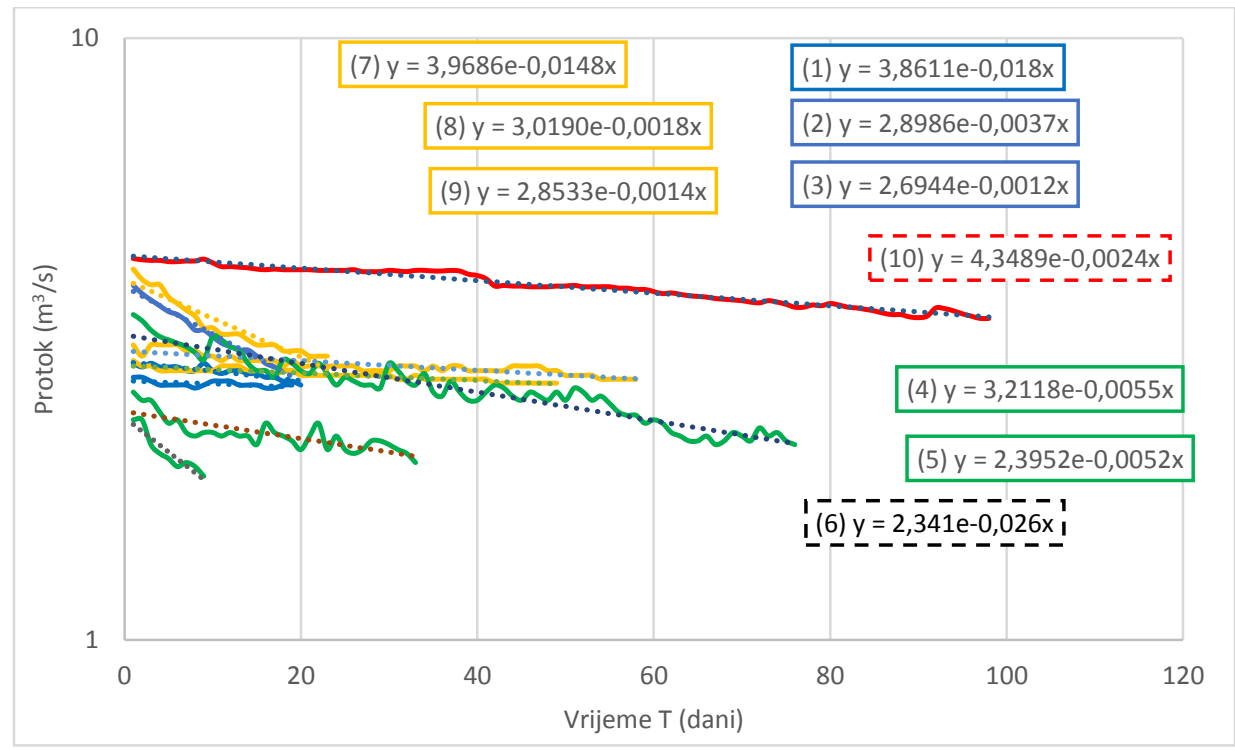

Slika 5. Krivulje recesije na postaji Izvor Gacka (1995.-2016.)

Prema Tablici 1, $\mathrm{Q}_{15}$ predstavlja procijenjenu vrijednost protoka nakon 15 dana, $Q_{30}$ - vrijednost protoka nakon 30 dana, $Q_{60}$ - vrijednost protoka nakon 60 dana, $Q_{90}$ - vrijednost protoka nakon 90 dana.

Tablica 1. Usporedba rezultata pražnjenja podzemnih vodonosnika krivuljama recesije za dane postaje s prognozom smanjivanja protoka u slučaju produljenja sušnog razdoblja

\begin{tabular}{|c|c|c|c|c|c|c|}
\hline Postaja & $\begin{array}{l}\text { Mjerodavna } \\
\text { krivulja }\end{array}$ & $\begin{array}{c}Q_{0} \\
\left(m^{3} / s\right)\end{array}$ & $\begin{array}{c}Q_{15} \\
\left(\mathrm{~m}^{3} / \mathrm{s}\right)\end{array}$ & $\begin{array}{c}Q_{30} \\
\left(\mathrm{~m}^{3} / \mathrm{s}\right)\end{array}$ & $\begin{array}{c}Q_{60} \\
\left(\mathrm{~m}^{3} / \mathrm{s}\right)\end{array}$ & $\begin{array}{c}Q_{90} \\
\left(\mathrm{~m}^{3} / \mathrm{s}\right)\end{array}$ \\
\hline $\begin{array}{l}\text { Čovići - } \\
\text { Gacka }\end{array}$ & (1) & 0,742 & 0,699 & 0,658 & 0,584 & 0,518 \\
\hline $\begin{array}{l}\text { Izvor } \\
\text { Gacka }\end{array}$ & (2) & 0,742 & 0,716 & 0,632 & 0,290 & 0,133 \\
\hline
\end{tabular}

Prema rezultatima, koji su prikazani u Tablici 1 , na osnovu bržeg pada protoka, ali i većih koeficijenata recesije, zaključuje se da su puno brža istjecanja akumulirane vode u podzemnom krškom vodonosniku na samom Izvora Gacke u odnosu na profil Čovići (Gacka) koji se nalazi praktički na izlazu iz izvorišne zone, i prikuplja sve izvorišne ogranke rijeke Gacke izuzev izvora Pećine. Koeficijenti recesije u oba slučaja ukazuju na sporije pražnjenje pri većim protocima, što može biti rezultat ne samo uvjeta u podzemlju, nego i hidroloških prilika tijekom recesijskog razdoblja, odnosno utjecaja palih oborina na prihranjivanje podzemlja kojih u načelu 
ne bi smjelo biti ako se želi dobiti stvarni režim pražnjenja podzemnih vodnih rezervi.

Analiza krivulje recesija proširena je analizom procjene količine napajanja podzemne vode na postaji Čovići pomoću alata VBM, a rezultati su prikazani u Tablici 2. Na osnovu već izrađenih hidrograma za 2001., 2006. i 2013. godinu, na postaji Čovići određene su po dvije krivulje recesije za svaki godinu na osnovu kojih se analizirala količina napajanja prema već spomenutoj metodologiji. U konačnici se došlo do zaključka da do najveće količine napajanja dolazi između dvaju krivulja recesije u 2013. godini u iznosu od 107,5 mil. $\mathrm{m}^{3}$ (Tablica 2).

Tablica 2. Prikaz rezultata napajanja podzemne vode na postaji Čovići

\begin{tabular}{|c|c|c|c|c|c|c|c|c|}
\hline \multicolumn{3}{|c|}{ 14.5. - 31.5.2001. } & \multicolumn{3}{|c|}{ 21.6. - 24.8.2006. } & \multicolumn{3}{|c|}{ 19.6. - 7.7.2013. } \\
\hline Const. a & $-0,01196$ & & Const. a & $-0,00760$ & & Const. a & $-0,01035$ & \\
\hline Const. b & 10,48480 & & Const. b & 10,65895 & & nst. b & 9,2 & \\
\hline$Q_{0}=$ & 10,800 & $\mathrm{~m}^{3} / \mathrm{s}$ & $Q_{0}=$ & 11,200 & $\mathrm{~m}^{3} / \mathrm{s}$ & $Q_{0}=$ & 9,430 & $\mathrm{~m}^{3} / \mathrm{s}$ \\
\hline$t_{(1 \log )}=$ & 190 & $\mathrm{~s}$ & $t_{(1 \log )}=$ & 291 & $\mathrm{~s}$ & $t_{(1 \log )}=$ & 221 & $\mathrm{~s}$ \\
\hline$V_{t p=}$ & 77.107 .386 & $\mathrm{~m}^{3}$ & $V_{t p=}$ & 124.755 .824 & $\mathrm{~m}^{3}$ & $V_{t p=}$ & 78.258 .657 & $\mathrm{~m}^{3}$ \\
\hline $\mathbf{t}$ & 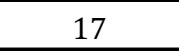 & $\mathrm{s}$ & t & 64 & $s$ & $\mathbf{t}$ & 18 & $\mathrm{~s}$ \\
\hline$V_{a}=$ & 14.352 .198 & $\mathrm{~m}^{3}$ & $V_{a}=$ & 48.858 .715 & $\mathrm{~m}^{3}$ & $V_{a}=$ & 13.387 .016 & $\mathrm{~m}^{3}$ \\
\hline \multicolumn{3}{|c|}{ 26.6. - 22.8.2001. } & \multicolumn{3}{|c|}{ 12.10. - 18.11.2006. } & \multicolumn{3}{|c|}{ 11.7. - 24.9.2013. } \\
\hline Const. a & $-0,00424$ & & Const. a & $-0,00646$ & & Const. a & $-0,00390$ & \\
\hline Const. b & 8,05056 & & Const. b & 5,74422 & & Const. b & 7,74502 & \\
\hline$Q_{0}=$ & 8,100 & $\mathrm{~m}^{3} / \mathrm{s}$ & $20=$ & 5,810 & $\mathrm{~m}^{3} / \mathrm{s}$ & $Q_{0}=$ & 7,780 & $\mathrm{~m}^{3} / \mathrm{s}$ \\
\hline$t_{(1 \log )}=$ & 542 & $\mathrm{~s}$ & $t_{(1 \log )}=$ & 355 & $\mathrm{~s}$ & $t_{(1 \log )}=$ & 590 & $\mathrm{~s}$ \\
\hline$V_{t p=}$ & 164.930 .096 & $\mathrm{~m}^{3}$ & $\mathrm{tp}=$ & 77.430 .765 & $\mathrm{~m}^{3}$ & $t p=$ & 172.419 .100 & $\mathrm{~m}^{3}$ \\
\hline \multicolumn{3}{|c|}{ Prihranjivanje } & \multicolumn{3}{|c|}{ Prihranjivanje } & \multicolumn{3}{|c|}{ Prihranjivanje } \\
\hline $\mathbf{R}=$ & 102.174 .908 & $\mathrm{~m}^{3}$ & $\mathrm{~K}=$ & 1.533 .656 & $\mathrm{~m}^{3}$ & $\mathbf{R}=$ & 107.547 .459 & $\mathrm{~m}^{3}$ \\
\hline
\end{tabular}

\subsection{Produljenje niza hidroloških podataka (pomoću metode strojnog učenja)}

Glavni cilj modeliranja bio je produžiti niz dnevnih podataka o protocima na postaji Čovići za period od 6.1.1988. do 31.12.1994. (ukupno 2552 podatka), s obzirom da su dnevni podaci u periodu od 6.1.1988. do 31.12.2016. (ukupno 39800 podatka) na postajama Izvor Gacka, SinacTonković vrelo i Ličko Lešće-izvor Pećina bili kontinuirano motreni i zabilježeni. Kako bi se dobile tražene predviđene vrijednosti o protocima, prije svega su izgrađeni modeli na osnovu postojećih podataka te su isti 
analizirani. Pri izradi modela korištena su dva klasifikacijska algoritma - MP i M5P.

Oba modela temelje se na 1 nezavisnoj varijabli, s tim da je u prvom modelu (u nastavku M1) uzeta 1 varijabla (protok) s 4 postaje, dok je u drugom modelu (u nastavku M2) uzeta također jedna varijabla, ali za 4 različita trajanja (dnevni protoci, srednja vrijednost protoka za 15, 30 i 60 dana) s 3 postaje.

Ključna razlika između ova dva modela je u broju zavisnih varijabli kao ulaznih podataka. Pri izradi M1 i M2 modela korištena su oba klasifikacijska algoritma - MP i M5P. Za oba izgrađena modela korišteni su dostupni podaci o dnevnim protocima na sve četiri postaje u periodu od 1995. do 2016. unutar kojih su nizovi podataka podijeljeni na dva dijela, odnosno trening i test (verifikacija modela). Ukupan broj podataka korištenih u modelu M1 iznosi 32144, dok u modelu M2 iznosi 104455. Za trening podataka unutar M1 modela korišteni su podaci od 2000. do 2016. godine (24840 podataka), dok su za test odnosno verifikaciju modela korišteni podaci od 1995. do 1999. godine (7304 podatka). Pri treniranju modela M2 za period od 2000. do 2016. godine, broj korištenih podataka iznosi 80717 , dok pri testiranju 23738 podataka za period od 1995 . do 1999. godine. Treniranjem i testiranjem modela dobiveni su statistički parametri modela prikazanih u Tablici 3, a koji su korišteni pri ocjeni kvalitete modela.

Tablica 3. Usporedba statističkih parametara treniranih i testiranih modela M1 i M2 pomoću algoritma M5P i MP

\begin{tabular}{|c|c|c|c|c|}
\hline \multirow[b]{2}{*}{ M5P } & \multicolumn{2}{|c|}{$\begin{array}{l}\text { Trening modela } \\
(2000 .-2016 .)\end{array}$} & \multicolumn{2}{|c|}{$\begin{array}{l}\text { Test modela } \\
(1995 .-1999 .)\end{array}$} \\
\hline & M1 & M2 & M1 & M2 \\
\hline Koeficijent korelacije & 0,9407 & 0,9497 & 0,8968 & 0,9189 \\
\hline $\begin{array}{l}\text { Srednja apsolutna } \\
\text { pogreška }\left[\mathrm{m}^{3} / \mathrm{s}\right]\end{array}$ & 1,7798 & 1,6694 & 2,309 & 2,1736 \\
\hline $\begin{array}{l}\text { Korijen iz sr. } \\
\text { kvadratne pog. }\left[\mathrm{m}^{3} / \mathrm{s}\right]\end{array}$ & 2,5766 & 2,3715 & 3,2898 & 2,9821 \\
\hline MP & M1 & M2 & M1 & M2 \\
\hline Koeficijent korelacije & 0,9649 & 0,9713 & 0,9226 & 0,9136 \\
\hline $\begin{array}{l}\text { Srednja apsolutna } \\
\text { pogreška }\left[\mathrm{m}^{3} / \mathrm{s}\right]\end{array}$ & 1,9332 & 1,3402 & 2,6502 & 2,2937 \\
\hline $\begin{array}{l}\text { Korijen iz sr. } \\
\text { kvadratne pog. }\left[\mathrm{m}^{3} / \mathrm{s}\right]\end{array}$ & 2,6013 & 1,8335 & 3,3308 & 3,053 \\
\hline
\end{tabular}


Dobiveni parametri prema testiranim vrijednostima ukazuju da je bolja varijanta model M2 prema klasifikacijskom algoritmu M5P, odnosno regresijskom stablu odlučivanja, na što ukazuje veći koeficijent korelacije, manja vrijednost srednje apsolutne pogreške i manja vrijednost korijena iz srednje kvadratne pogreške u odnosu na model M1. Na osnovu modela M2 je produžen niz na postaji Čovići.

U nastavku je dan prikaz usporedbe stvarnih i modeliranih vrijednosti modela M2 prema oba algoritma za razdoblje od 1995. do 1999. (Slika 6). Ono što možemo uočiti jeste da se javljaju podjednaka odstupanja u oba slučaja. U većini slučajeva predviđene vrijednosti prema algoritmu M5P su bliže stvarnim vrijednostima u odnosu na vrijednosti prema MP algoritmu.

Nakon modeliranja postojećih podataka te analiza, na osnovu bolje varijante izgrađen je model za nadopunu niza na postaji Čovići (Slika 7) u periodu od 6.1.1988. do 31.12.1994. (2552 podatka). Model za nadopunu baziran je na modelu M2, a pri izgradnji je korišten klasifikacijski algoritam M5P. Ukupan broj korištenih podataka pri izradi modela je 137644, za trening modela je korišteno 104468, dok se za verifikaciju (test) modela koristilo 33491 podataka. Na Slici 7 uočavaju se veća odstupanja stvarnih i modeliranih vrijednosti pri maksimalnim vrijednostima protoka.

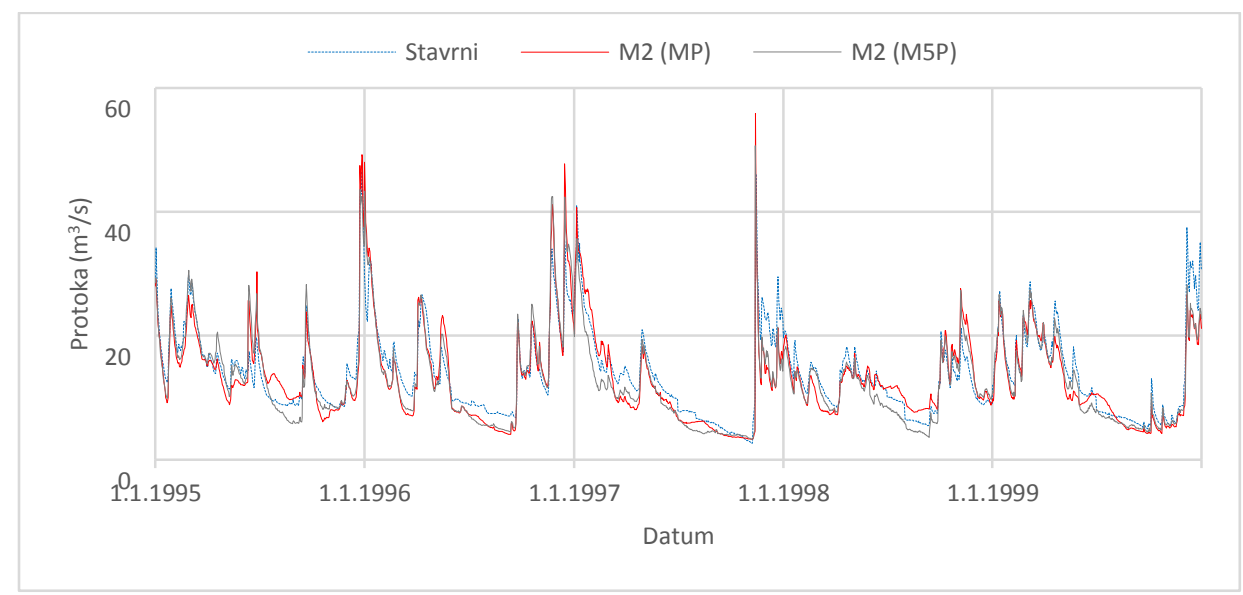

Slika 6. Usporedba testiranih stvarnih i modeliranih vrijednosti modela M2 pomoću algoritama M5P i MP 


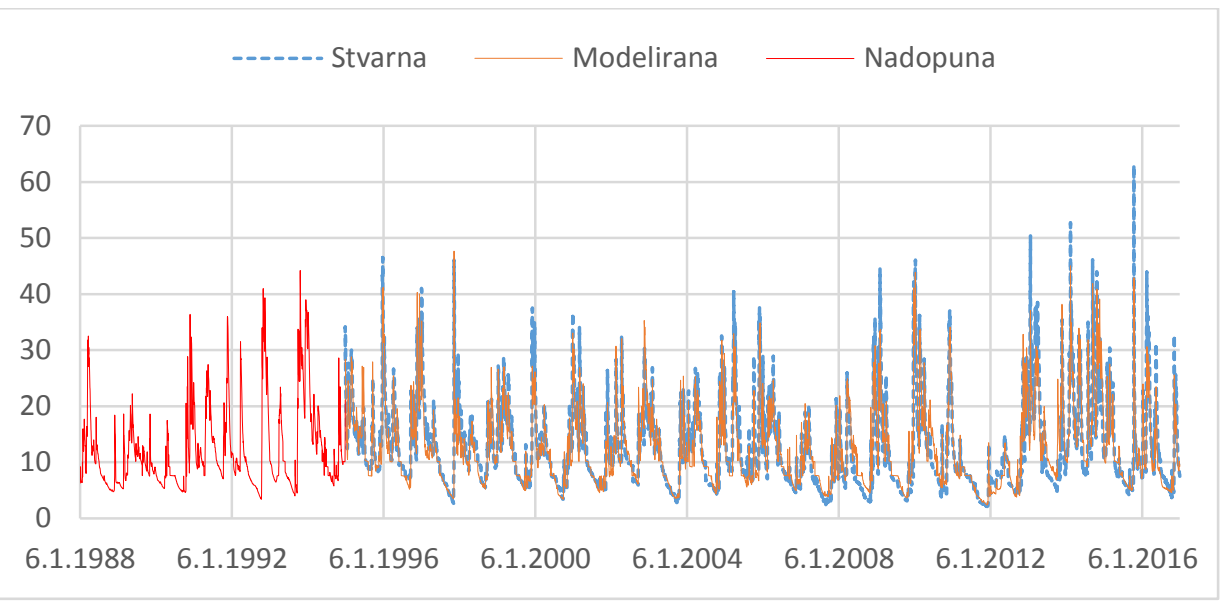

Slika 7. Grafički prikaz stvarnih i modelom regresijskih stabla (M5P) proračunatih vrijednosti dnevnih protoka na postaji Ćović za trenirano i testirano (1996.-2016.) te nadopunjeno razdoblje (6.1.1988.-31.12.1994.)

\section{Zaključak}

Cilj ovog rada je provedba analize hidroloških procesa na izvorišnom dijelu rijeke Gacke koja obuhvaća analizu glavnih izvora Gacke i Tonković vrela, izvora Pećina na Gackinoj pritoci Kostelki te na postaji Čovići na Gackoj na kojoj se registriraju skupni protoci svih izvora i površinskih bilančnih doprinosa rijeke Gacke uzvodno od pritoke Kostelke.

Analizom godišnjih protoka ustanovljeno je da se na sve četiri postaje bilježe blagi rastući trend za promatrani niz od 1997. do 2016. godine. Provedenom analizom mjesečnih protoka na izvorišnom dijelu rijeke Gacke utvrđeno je da sva tri hidrološka profila nemaju velikih varijacija protoka, odnosno izdašnosti izvora, kako unutargodišnjih, tako i višegodišnjih. Na temelju analize krivulja recesije za postaju Čovići i Izvor Gacka, pomoću koeficijenata recesije i usporedbom mjerodavnih krivulja ustanovljeno je da brže pražnjenje odnosno dreniranje vode ima područje izvora Gacke u odnosu na cjelokupne vode Gacke do postaje Čovići, što je i razumljivo obzirom na veći broj izvora čije vode prihranjuju Gacku do tog profila.

Modelirani su podaci sa izvorišnog dijela rijeke Gacke i postaje Čović te su izgrađena dva modela M1 i M2 i to modeliranih s algoritmima neuronskim mrežama (MP) i regresijskim stablima odlučivanja (M5P). Analizom modela te odabirom kvalitetnijeg modela na osnovu statističkih parametara ustanovljeno je da je bolja varijanta M2 model prema algoritmu M5P. Na osnovu bolje varijante izrađen je model i nadopuna podataka na postaji Čovići kod kojeg odstupanja bivaju veća pri maksimalnim vrijednostima stvarnih protoka. 


\section{Literatura}

[1] Hrvatske vode. (2016) Plan upravljanja vodnim područjima 2016. - 2021.

[2] Posavec, K., Parlov, J., i Bačani, A. (2009) A Visual Basic Spreadsheet Macro for Estimating Groundwater Recharge. Rudarsko-geološko-naftni zbornik. Zagreb: Rudarsko-geološko-naftni fakultet Sveučilišta u Zagrebu, str. 19-23. Preuzeto s: https://hrcak.srce.hr/47247 (Preuzeto: 17.03.2018.)

[3] Dinarsko gorje. https://www.dinarskogorje.com/b23-li269kosredogorje.html (preuzeto 19.3.2018.)

[4] Elektroprojekt d.d. Zagreb. (2007) Plan navodnjavanja Ličko-senjske županije. Knjiga I, prilog 3 - Prikaz postojeće dokumentacije, Zagreb, str. 4-14

[5] DHMZ. http://klima.hr/k1 (preuzeto 19.3.2018.)

[6] Bonacci, O., Andrić, I. (2009) Zajednička hidrološka analiza Like i Gacke. Hrvatske vode: Časopis za vodno gospodarstvo, 17/2009/67, str. 1-12.

[7] Institut IGH d.d. Zagreb, (2016) Elaborat zaštite okoliša - Sustav javne odvodnje i pročišćavanja otpadnih voda aglomeracije Otočac. Zagreb, br. proj. 85013703, str. 76-196

[8] Božićević, S. (1992) Fenomen krš. Zagreb: Školska knjiga.

[9] Hidro consult d.o.o. Rijeka (2001) Vodoopskrbni plan Ličko-senjske županije, br. proj. 205.

[10] Elektroprojekt d.d. Zagreb. (2007) Plan navodnjavanja Ličko-senjske županije. Knjiga III, prilog 4 - Voda za navodnjavanje, Zagreb, str. 15-17

[11] Maillet, E. (1905) Essais d'Hydraulique Souterraine et Fluviale, Hermann, Paris

[12] Krešić, N. (1997) Hydrogeology and Groundwater Modeling. Lewis Publishers New York: CRC Press, 1-461.

[13] Meyboom, P. (1961) Estimating Ground-Water Recharge from Stream Hydrographs. Journal of Geophysical Research, 66(4). 1203-1214.

[14] The University of Waikato. http://www.cs.waikato.ac.nz/ml/weka/ (preuzeto 22.5.2018)

[15] DMS. http://dms.irb.hr/tutorial/hr tut dtrees.php (pristup 22.5.2018) 